\title{
O(s) Prémio(s) da Crítica 2007 Uma realidade vasta e plural
}

Maria Helena Serôdio

Foi uma vez mais no belíssimo Jardim de Inverno, amavelmente cedido pelo director do São Luiz Teatro Municipal, Professor Jorge Salavisa, que a Associação Portuguesa de Críticos de Teatro celebrou, a 10 de Março, o teatro que se fez, escreveu, editou e mobilizou em 2007. Fê-lo na cerimónia simbólica de atribuição do Prémio da Crítica, e é esse o momento que queremos aqui relembrar através dos textos que fundamentam as opções do júri, formado desta vez por Ana Pais, Constança Carvalho Homem, João Carneiro, Maria Helena Serôdio e Rui Pina Coelho.

0 aspecto que mais gostaria de salientar a propósito das distinções atribuídas este ano é o facto de a realidade que opera em teatro ser vasta e plural, e essa é a razão pela qual o júri distinguiu não apenas os que em cena nos desafiam, comovem, alegram e surpreendem, mas também os que se movimentam em torno desse mundo, antecipandoo ou envolvendo-o em projectos de importante alcance cultural e artístico.

Recordamos, assim, que a Associação Portuguesa de Críticos de Teatro atribuiu o Prémio da Crítica, relativo ao ano de 2007, ex-aequo ao espectáculo A tragédia de Júlio César, uma co-produção do Teatro da Cornucópia e do São Luiz Teatro Municipal, e ao espectáculo Foder e ir às compras, uma co-produção da companhia Primeiros Sintomas e do Centro Cultural de Belém, tendo sido, em cada caso, o galardão entregue aos respectivos encenadores: Luis Miguel Cintra e Gonçalo Amorim.

As Menções Especiais foram atribuídas à actriz Emilia Silvestre, ao projecto PANOS (Palcos novos / Palavras novas) - na pessoa do Programador de Teatro da Culturgest, Francisco Frazão - e à editora Livros Cotovia, na pessoa do seu Director, André Jorge (representado na sessão por Mafalda Azevedo).
Sobre as razões que fundamentaram estas escolhas - e que aqui são relembradas, como julgamos importante para esclarecer critérios de valoração - a verdade é que apontam para o que nestas distinções serve também para celebrar a memória futurante que no teatro tão esplendidamente se realiza.

De facto, sabemos como há entre o teatro e a memória uma permanente negociação cultural, mas não se trata apenas de referir nessa expressão que o teatro é lugar de assombração porque revisita textos, figuras ou acções do passado, mas também, e sobretudo, porque ele próprio faz a memória, articula - figurativamente - lugares do pensamento, da história, da fição e do sonho, que são, afinal, a raiz do humano. E essa é uma evidência teórica em que se lêem razões da arte, da história, da filosofia, da psicologia, da sociologia, enfim, dos lugares do pensamento e acção que celebram e nos fazem reconhecer o predicamento humano. Não por acaso, Hamlet diz serem os actores "os modelos e as breves crónicas do tempo" (II, 2)

Um outro poeta, este mais próximo de nós - Manuel Gusmão - ao procurar figuratividades que modalizam "o alphabeto", refere, num dos seus poemas, que "através de muitos anos o actor vem caindo/ sobre o palco como um pequeno fogo inicial/ transformando-se" (Dois sóis, a rosa. A arquitectura do mundo, 1990: 50).

Essa capacidade que o teatro tem - e que nós celebramos - será aqui lembrada e aplaudida nas suas variadas instâncias. Se é certo que os "diplomas", que atribuimos, são um artefacto modesto, a verdade é que neles investimos o nosso mais sincero tributo enquanto testemunhas atentas e celebrantes que somos e queremos continuar a ser. E, para além deles, aqui ficam as palavras que registamos também para o futuro. 


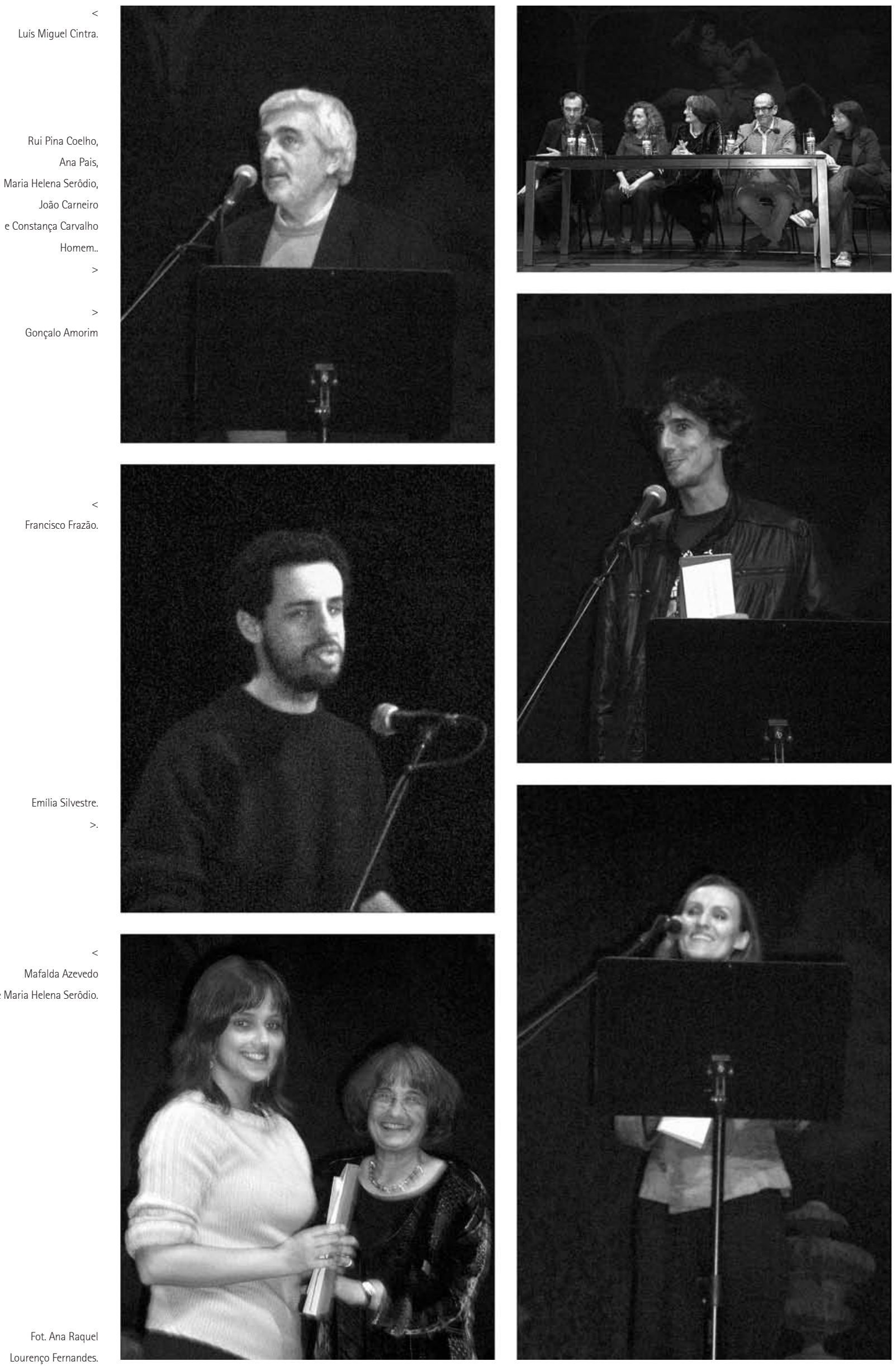

